\title{
The most common oral cavity ailments in geriatric patients
}

\author{
Najczęstsze dolegliwości w jamie ustnej u pacjentów geriatrycznych
}

\author{
Kamil Bijowski ${ }^{1, D \oplus}$, Zofia Dąbrowska ${ }^{2, D \oplus}$, Barbara Onopiuk ${ }^{3, D \oplus}$, Ewa Dąbrowska ${ }^{4, D \oplus}$, \\ Mariusz Zagajewski ${ }^{5, D}$ ( \\ ${ }^{1}$ Non Public Health Care Unit 'Dental' Katarzyna Bijowska, Białystok, Poland \\ ${ }^{2}$ Doctoral Study, Department of Periodontal and Oral Mucosa Diseases, Faculty of Medicine, Medical University \\ Białystok, Poland \\ ${ }^{3}$ Non Public Health Care Unit 'Family Dentistry', Białystok, Poland \\ ${ }^{4}$ Independent Gerostomatology Laboratory, Medical University, Białystok, Poland \\ ${ }^{5}$ Department of Plastic, Reconstructive and Aesthetic Surgery, Norbert Barlicki University Teaching Hospital No. 1, Łódź, \\ Poland
}

A - Research concept and design, B - Collection and/or assembly of data, C - Data analysis and interpretation, $D$ - Writing the article, E-Critical revision of the article, F- Final approval of article

Bijowski K, Dąbrowska Zofia, Onopiuk B, Dąbrowska E, Zagajewski M. The most common oral cavity ailments in geriatric patients. Med Og Nauk Zdr. 2021; 27(1): 23-31. doi: 10.26444/monz/133399

\begin{abstract}
Introduction. Demographic forecasts for the Polish population indicate that in 2030 in Poland, that the elderly will constitute approximately $24 \%$ of the population. Functional dentition and providing physiological and social benefis are part of the physical and mental well-being of an elderly patient with missing dentition and general diseases.

Objective. The aim of the study is to discusses the most common ailments encountered in geriatric patients treated by dentists. Etiology, characteristics and treatment options for the described ailments are taken into account. In dental treated patients age over 60 , the most common problems encountered are: stomatopathies, xerostomia and burning mouth syndrome (BMS). Stomatopathies werethe most common in diabetic patients, and in patients using removable or fixed prosthetic restorations.

Materials and method. Analysis of the assumed aims of the paper was carried out based on the available literature. Particular attention was paid to the most common complaints in elderly patients.

Conclusions. All the above-listed oral cavity health conditions affect the well-being, i.e. physical and mental health of a patient. Local pathological states, such as prosthetic stomatopathies, pass mainly by eliminating the cause of contact inflammation. Other ailments: periodontitis, BMS or xerostomia, are closely related to the general condition of the patient. Changes in the oral cavity depend on the intensity and stabilization of the general disease. His is the reason that a very important role is played by the attending physicians: diabetologists, neurologists or psychiatrists. The cooperation of a dentist with a general practitioner can significantly improve the health of geriatric patients.
\end{abstract}

\section{Keywords}

Xerostomia, BMS, Stomatopathies, geriatric patients

\begin{abstract}
Streszczenie
Wstęp. Prognozy demograficzne dla populacji polskiej wskazują, że w Polsce w 2030 roku około 24\% populacji będą stanowiły osoby starsze. Funkcjonalne uzębienie, zapewniające korzyści fizjologiczne i socjalne, jest elementem dobrostanu fizycznego i psychicznego pacjenta w podeszłym wieku z brakami w uzębieniu i chorobami ogólnymi.

Cel pracy. W niniejszej pracy omówiono najczęstsze dolegliwości spotykane u przyjmowanych przez dentystów pacjentów geriatrycznych. Uwzględniono etiologię, charakterystykę oraz możliwości leczenia opisanych dolegliwości. U leczonych stomatologicznie pacjentów po 60. roku życia najczęściej występującymi problemami były: stomatopatie, kserostomia i zespół pieczenia jamy ustnej (BMS). Stomatopatie najczęściej występowały u pacjentów chorujących na cukrzycę oraz u osób użytkujących ruchome lub stałe uzupełnienia protetyczne.

Materiał i metody. Na podstawie dostępnego piśmiennictwa przeprowadzono analizę założonych celów pracy.

Podsumowanie. Wszystkie ww. schorzenia dotyczące zdrowia jamy ustnej mają wpływ na dobrostan, czyli zdrowie fizyczne i psychiczne, pacjenta. Schorzenia o etiologii miejscowej, jak stomatopatie protetyczne, mijają głównie dzięki eliminacji przyczyny kontaktowego zapalenia. Pozostałe dolegliwości: zapalenie przyzębia, BMS czy kserostomia są ściśle powiązane ze stanem ogólnym pacjenta. Wówczas zmiany w jamie ustnej zależą od intensywności i wyrównania choroby ogólnej. Dlatego bardzo ważną rolę odgrywają lekarze prowadzący: diabetolodzy, neurolodzy czy psychiatrzy. Współpraca lekarza dentysty z lekarzem ogólnym może znacznie wpłynąć na poprawę zdrowia pacjentów geriatrycznych.
\end{abstract}

\section{Słowa kluczowe}

stomatopatie, kserostomia, BMS, pacjenci geriatryczni 


\section{INTRODUCTION}

Oral cavity is an integral part of the body which should always be taken into account in the examination of the patient by the primary care physician or dentist. Patients of all ages may be affected by clinical changes in the oral cavity, but geriatric patients with a history of general diseases and related pharmacological treatment often report problems with the masticatory apparatus. Thus, the diagnosis and treatment of lesions in the oral cavity requires an interdisciplinary team which includes a general practitioner, a specialist doctor and a dentist.

The low population growth recorded mainly in developed countries and improved life expectancy increases the population of those at a very advanced age [1]. The quality of life does not always improve along with the increase in life expectancy, one of the criteria of which is maintaining oral health. Functional dentition, providing biological (chewing, taste, speech) and social (aesthetics, comfort) benefits, is an element of physical and mental well-being. Therefore, modern dentistry is facing more and more problems related to the treatment of elderly patients [2].

Prosthetic stomatopathies. These are conditions affecting patients who use full or partial acrylic dentures. The worldwide prevalence of stomatopathy among patients patients using removable dentures is about $30-36 \%$. Research by Arnaud et al. shows that the problem of stomatopathy more often affects the group of the elderly aged over $60[3,4]$.

The characteristic feature of prosthetic stomatopathy is redness and swelling of the jaw mucosa covered by the denture plate. The surface is light or dark red in colour and is sharply demarcated from the adjacent tissues; therefore, it closely coincides with the prosthetic area. Inflammation of the prosthetic base mucosa in the mandible is usually less intense than in the maxilla, and in many cases it does not occur at all. This pathological state may affect up to $70 \%$ of patients using removable, functionally unstable dentures [5].

The Newton classification is the most frequently used classification of prosthetic stomatopathy among Polish dentists, based on clinical evaluation, which distinguishes between three types of inflammation. The first degree includes a limited inflammatory state on the unchanged mucosa around the openings of the palatine ducts of the mucous glands. The second stage is characterized by extensive hyperaemia of the mucosa covered by the denture plate. The third stage shows hypertrophic granulomatous inflammation, which may extend beyond the area covered with the denture plate [6].

The occurrence of prosthetic stomatopathy is usually multifactorial. The local factors include long-term use of removable dentures with poor retention and stabilization (mechanical trauma), poor oral hygiene, and prosthetic restorations along with their 24-hour use (biofilm formation). In the study by Smolana et al., the majority of patients using dentures 24 hours a day showed changes defined as Newton class II. In this group, as the only one, there were two cases of hypertrophic granulomatous inflammation of the mucosa [7]. Other local causes of stomatopathy are the insufficient smoothness and absorbability of the acrylic material, which increases with the service life of the restorations, the toxic effect of free monomer and electrochemical reactions that may occur during the contact of dental alloys with the oral cavity.
General factors that influence the development of prosthetic stomatopathy include smoking, diabetes, immuno-suppression, diseases requiring chronic antibiotic therapy, steroid therap, or the use of psychotropic drugs [8]. Mechanical trauma caused by a poorly adjusted denture results in the occurrence of disorders within one of the basic protective barriers of the oral cavity - the mucosa, and may become the gate of infection, e.g. for fungi of the genus Candida or bacteria [9]. According to research by Gauch et al., Candida spp. were isolated in $89 \%$ of denture patients suffering from stomatopathy [10]. Another cause of stomatopathy is the adherence of microorganisms to the denture plate, mainly due to poor hygiene. Biofilm formation consists of two phases which occur one after the other. The first is the non-specific and reversible phase, which is based on the adhesion of microorganisms to the surface of the biomaterial using non-specific van der Waals and electrostatic interactions. The following second phase consists in specific interactions between different types of microorganisms, with Candida albicans playing the biggest role. Subsequently, a three-dimensional structure of the biofilm is formed which is much more difficult to remove and more resistant to pharmacological antifungal treatment [11].

Smoking is a factor that strengthens stomatopathy and effects the development of stomatopathy, related to the heat generated by tobacco products. Temperatures that a burning tobacco cigarette reaches are, on average, $650^{\circ} \mathrm{C}\left(470-812^{\circ} \mathrm{C}\right)$, while the temperature of the core of the cigarette can reach $824^{\circ} \mathrm{C}-897^{\circ} \mathrm{C}$. High temperature and the smoke coming into direct contact with the palate causes irritation and inflammation in the area of openings of the minor salivary glands on the hard palate [12]. As reported by Jones et al., histological changes in the course of stomatopathy occurred only in $2 / 3$ of the hard palate. The authors observed no nicotinic stomatitis in $1 / 3$ of the anterior part of the hard palate and the soft palate. This is due to the low distribution of small salivary glands on $1 / 3$ of the anterior part of the hard and soft palates [13].

Poor hygiene of dentures causes the accumulation of biofilm, and thus the growth of bacteria and fungi, making the mucosa susceptible to inflammatory processes. The main way to prevent and treat stomatopathy is to maintain proper hygiene of the oral cavity and dentures [14]. Several mechanical and chemical methods, isolated or related, can be used to clean the dentures, such as: brushing the dentures under running water; brushing the denture with toothpaste; brushing with ordinary soap; cleaning with sodium hypochlorite (1.5-2.0\%); immersion in sodium hypochlorite $(0.10-0.20 \%)$; immersion in baking soda; immersion in alkaline peroxide; immersion in mouthwashes; and the use of effervescent tablets. The primary role in the prevention and treatment of stomatitis, however, is played by the accuracy of prosthetic restoration cleaning, and not the method used [15].

Despite the clinical improvement resulting from hygienisation, it is often necessary to use antifungal agents to counteract a predetermined disease. Therefore, the treatment of choice in stomatopathy consists of a combination of antifungal agents, instructions on the importance of keeping the dentures clean, and verification of the need to replace the restoration with a new one. The most commonly used antifungal agents in treatment are miconazole, fluconazole, itraconazole, nystatin, amphotericin B, ketoconazole, 
clotrimazole and chlorhexidine [16]. Clotrimazole is a frequently applied topical antifungal agent used in the treatment of Candida-associated stomatopathy. Czerninski et al. compared the effectiveness of topically applied clotrimazole tablets (five tablets of $10 \mathrm{mg}$ / day) with clotrimazole varnish (50 mg / day) applied for 14 days. After microbiological analysis, the results showed a significantly lower level of Candida in the saliva of patients treated with varnish.

Nanomaterials are increasingly more often used in treatment [17]. Acosta-Torres et al. developed methyl methacrylate nanoparticle silver discs to prevent and treat stomatitis. Clinical results showed that nanoparticle discs significantly reduced the adhesion of C. albicans, and do not affect the metabolism or proliferation of denture base cells; their inclusion in the treatment of dentures is promising [18].

Difficult communication with an elderly patient and the often accompanying psychomotor limitations require frequent hygienic and nutritional instruction in patients who use dentures. This will contribute to the maintenance of a healthy oral cavity.

Diabetic stomathopaties. Diabetes is a chronic metabolic disease associated with hyperlipidaemia and hyperglycaemia. According to current estimates, 285 million adults aged 20-79 suffer from diabetes.

Diabetes-related symptoms that manifest in the oral cavity include: dry mouth, increased tooth decay, periodontal disease and gingivitis, oral candidiasis, burning mouth syndrome (BMS), taste disturbances, aspergillosis, oral lichen planus, geographic tongue, delayed wound healing and increased incidence of infections, disorders of secretion and properties of saliva $[19,20]$.

According to numerous studies, periodontal disease is the most common disease of the oral cavity in patients with decompensated diabetes and accounts for approx.34\% of all lesions in the oral cavity [21]. Lim et al., on the basis of a study of 16,720 people, showed a relationship between insulin resistance and periodontitis in Korean postmenopausal women [22]. Research by Wyszyńska et al. showed that in a group of patients treated for diabetes, the presence of deeper pockets and greater loss of connective tissue attachment were observed, which were largely correlated with the age of the patients, in this case higher than in newly- diagnosed patients [23].

The adverse effect of diabetes on periodontium is associated with disturbances in collagen metabolism, impaired neutrophil function and reduced repair capacity of periodontal tissues; in terms of incidence, periodontitis is considered the main complication of diabetes [24]. In the studies by Wilczyńska-Borawska et al., it was found that the highest degree of loss of connective tissue attachment was found in people with diabetes (CAL $\geq 5 \mathrm{~mm}$ ), especially in women [25].

Physiological chewing can cause the systemic spread of periodontal pathogens and their metabolic products, and hence cause systemic endotoxaemia or bacteraemia which lead to an increase in inflammatory mediators, such as interleukin 6 (IL-6), fibrinogen and C-active protein (CRP). Systemic inflammation caused by this mechanism can exacerbate insulin resistance and thus make diabetes management more difficult. For this reason, proper periodontal treatment may reduce the level of pro-inflammatory mediators, and thus contribute to better glycaemic control [26]. Studies by
Simposons et al. showed a statistically significant reduction in $\mathrm{HbAlc}$ by approximately $3-4 \mathrm{mmol} / \mathrm{mol}$ (approximately $0.3-0.4 \%)$ in the short term (3-4 months) after periodontal treatment in diabetic patients [27].

Mechanical removal of the subgingival plaque and tartar is also the basis for treatment of periodontitis in diabetic patients. This treatment may also significantly improve glycaemic parameters. Apart from mechanotherapy, proper control of bacterial plaque by the patient helps in successful treatment [28].

Decompensated diabetes also predisposes to oral candidiasis. As reported by Obradović et al., patients with type I and type II diabetes are almost equally exposed to Candida albicans infection, while in both groups the HbAlc values were, respectively: type I diabetes $-9.87 \pm 0.32 \%$, diabetes type II $-8.70 \pm 0.45 \%$, which indicates a poor state of diabetes control [29]. Premkumar et al. showed that in diabetic patients there is a much higher prevalence of $\mathrm{C}$. albicans strains in the oral cavity. The prevalence of Candida species in diabetics was $87.5 \%$, while in control group it was $50 \%$ [30]. In the study by Gomes et al., these values were $79.2 \%$ in patients with diabetes, and $20.8 \%$ in patients with normoglycaemia [31]. Development of oral candidiasis in patients with poorly controlled diabetes is complex and influenced by many factors. Patients with candidiasis show an increased level of glucose in the tissue fluid, which is a breeding ground for yeasts, reduced salivation, which facilitates their adhesion to the epithelium, and the use of acrylic dentures promotes the deposition of C. albicans on the surface of the denture plate [29].

Diabetes symptoms in the oral cavity can be prevented in many ways. The main task of the dentist is to motivate and teach the patient to regularly and properly brush and floss the teeth, encourage patients to visit the dentist for routine checkups, and monitor blood glucose levels [32].

Xerostomia (dry mouth). Xerostomia is a subjective feeling of dry mouth caused by decreased salivation. This problem affects millions of people worldwide. Normal salivation in adults is $0.5-1$ liters/day, of which only $2-10 \%$ of the saliva volume is released at night. Reduced salivation (hyposialia) that causes drying of the oral cavity mucosa is known as xerostomia (dryness), which occurs when less than $0.1 \mathrm{ml} /$ min of saliva is secreted. This disease occurs in the form of true and pseudo-xerostomia. True xerostomia (xerostomia vera, primaria) is the result of a malfunction of the salivary glands, while in pseudo-xerostomia (xerostomia spuria, symptomatica), dry mouth is not caused by poor salivary gland secretion. This condition is defined as the end effect of saliva drainage, i.e. the process of evaporation, adsorption to the mucosa and removal by ingestion. Xerostomia is usually characterized by pale and dry cheek mucosa, and dry, smooth or furrowed surface of the tongue. It is often accompanied by pain and burning sensation in the oral mucosa, reduced taste sensation, and deterioration in the ability to chew food. Dryness, which is the main symptom of xerostomia, may adversely affect the patient's speech and also impede the retention of prosthetic restorations such as full or partial dentures $[33,34]$. With age, the number of secretory cells of the salivary glands decreases in the process of physiological aging of the body. This process is especially visible in people over the age of 65 , more often in menopausal women. Also, Johansson et al. confirm that the 
incidence of xerostomia increases with age, and Minicucci et al. describe the effect of partial or complete reduction of estrogen production in perimenopausal and postmenopausal women on a significant reduction in salivation, resulting in xerostomy symptoms [35,36]. In some cases, dry mouth is the result of the general condition of the body, such as high fever, dehydration, heat stroke, vomiting or diarrhea. There are well-known conditions in the course of which decreased salivation is observed: primary and secondary Sjogren's syndrome, rheumatoid arthritis, diabetes type 1 and 2, Alzheimer's disease, scleroderma, sarcoidosis and AIDS [37]. The local causes that contribute to dry mouth are mainly smoking and breathing through open mouth due to obstruction of the upper respiratory tract. The use of full dentures is also of importance [38]. Some medications also negatively affect saliva production. As reported by Walis et al., the risk of dry mouth increases with the number of coexisting general diseases and medications taken [39]. In another study, Walis et al. found that the average age of the people suffering from xerostomia was 75.36 years (73.35 years for women; 77.37 years for men). The most frequently reported diseases in general medical interview were: hypertension (70\%), type II diabetes (20\%), and thyroid diseases (12\%). $4 \%$ of the respondents suffered from blood clotting disorders, prostatic hyperplasia or glaucoma, while $2 \%$ took pharmaceuticals for asthma, osteoporosis or depression. $90 \%$ of subjects were taking one to several medications chronically [40]. Among the medications most commonly taken by geriatric patients, and the side-effect of which is the induction of xerostomia, mainly medications with antidepressant effect should be mentioned: diuretics, al-antagonists (e.g. prazosin), antiarrhythmic (mainly beta-blockers), proton pump inhibitors, as well as benzodiazepines and opioids [41].

Saliva has the ability to dissolve nutrients, a process that plays a key role in the taste sensation process. As noted by Węgrzyn et al., this process is significantly impaired by xerostomia, which may translate into a decrease in appetite. Mucins present in saliva are also responsible for the formation of a food bite, which is an important element of the proper swallowing process. Saliva also has a digestive function because it contains amylase which is responsible for the initial digestion of food. Reducing its secretion has a negative effect on the digestive process. The consequence of these processes may be loss of appetite in the elderly, difficulties in the formation of a food bite, resulting in weight loss [42].

Cigarette smoke contains around 4,000 bioactive compounds, including cadmium and 300 carcinogens. Nicotine contained in tobacco acts on specific cholinergic receptors in the brain that cause neuronal activation, thereby increasing SFR (saliva flow rate) for a short time during smoking. Long-term use of tobacco leads to an increased action of adrenaline or the inactivation of taste receptors by nicotine, thus weakening the salivary reflex, reducing SFR or causing degeneration of the salivary glands [43]. Significant reduction in SFR in heavy smokers is confirmed by the studies by Shubha et al. In addition to reducing SFR, the authors also noted a decrease in saliva $\mathrm{pH}$ among smokers. Their results are based on the observation of patients with an average duration of addiction of $9.4 \pm 2.1$ years and smoking 8-10 \pm 3 cigarettes a day. A change in the quantity and quality of saliva, together with chronic irritation from cigarette smoke, makes the oral mucosa more susceptible to pathological changes [44].
The basis for the treatment and prevention of xerostomia is regular and proper oral hygiene. Patients with dry mouth problem should give up acidic, salty and dry foods, and eliminate smoking and alcohol consumption. However, treatment is limited mainly to symptomatic treatment which often uses herbal rinses (linseed, mallow flower, marshmallow). To improve the quality of life, various types of saliva substitutes are introduced into therapy $[33,38,45]$. Systemically acting salivators also play an important role in the treatment of xerostomia. One of the most commonly used groups of medications are parasympathomimetics for example, pilocarpine (available as $2 \%$ eye drops), used at a dose of five $\mathrm{mg}$ three times a day at a maximum dose of $30 \mathrm{mg} /$ day. However, it should be remembered that these medications should not be used in cases of asthma, and cardiac failure. While taking pilocarpine, particular care should be taken when driving vehicles and operating machinery, because in the event of a systemic effect, the medication may reduce visual acuity, especially in the evening and at night. Other medications with systemic effect are physostigmine and cevimeline [46]. Patient education is also an important element, and the patient should be encouraged to increase regular fluid intake, both with food and throughout the day, to ensure adequate hydration.

BMS (burning mouth syndrome). A chronic disorder characterized by burning, stinging and / or itching in the oral cavity in the absence of any organic disease. It lasts from at least four to six months, most often affects the tongue, and may also affect the lips and oral mucosa [47]. Sardella et al. found the prevalence of BMS in the general population to be between $0.5-5 \%$ [48]. Based on the definition proposed by the International Headache Society, which assumes that BMS is idiopathic, attempts have been made to identify factors associated with the possible etiopathogenesis of this condition. The adoption of such assumptions regarding the etiopathogenesis of BMS enabled classification as primary, idiopathic and secondary, in which risk factors were identified as local or systemic [49]. The etiology of this condition is believed to be multifactorial and includes various local, systemic and / or psychogenic causes. Female gender, perimenopausal period, depression, anxiety, Parkinson's disease and chronic diseases, including diseases of the gastrointestinal tract and the genitourinary system, are risk factors for the development of BMS [50]. Netto et al. stated that BMS has a clear predisposition to gender and age. Women are 2.5-7 times more common than men. The same authors found that BMS can also affect any age group, with the age of patients ranging from 27-87, mean age 61 years [47]. The study by Kohorst et al. found that the mean age at diagnosis of BMS was 59.4, the overall incidence was highest in the age group 70-79 years, while the highest dissemination was in women aged 70-79 [49]. It is also not without significance that, as reported by Souza et al., BMS has a negative impact on health-related quality of life [51].

Before establishing a treatment plan for each patient with BMS, clinicians should conduct a detailed review of the patient's medical and dental history, and carefully review the patient's data obtained from physical and laboratory tests. It is also necessary to check whether the patient's symptoms are due to para-functional habits, galvanic current, mechanical irritation, allergic reaction, infection, anaemia, mineral or nutritional deficiencies, medications, as 
well as gastrointestinal, urogenital, psychiatric, neurological and metabolic disorders [52, 53, 54]. Corsalini et al have documented that bruxism, myofascial pain in the masticatory muscles and temporomandibular disorders coexist with burning in the mouth [55]. According to a retrospective analysis of the Mayo Clinic serological tests in patients with BMS, vitamin B1, B2, B6 and zinc deficiencies were associated with BMS and recommended for screening patients with these symptoms [56]. As reported by Watanabe et al., patients suffering from gastroesophageal reflux disease (GERD) also experience burning sensation in the mouth [57].

In case of doubts as to the etiopathogenesis of BMS, the attending physician should order additional tests, i.e. blood and saliva measurements, imaging, such as MRI and computed tomography, and ask the patient to complete a psychological questionnaires [58]. The attending physician should also determine if the patient has primary or secondary BMS. Treatment or elimination of local, systemic or psychological factors usually results in a significant clinical improvement in burning mouth and pain symptoms. If symptoms persist after the potential causes have been eliminated, pharmacological treatment should be started. Previous randomized, controlled trials have shown that pharmacological treatment with capsaicin, alpha lipoic acid, clonazepam, and antidepressants can relieve burning mouth or pain symptoms. Capsaicin is used both topically and systemically in BMS treatment to relieve symptoms. When applied topically, it has the ability to bind to the TRPV1 ion channels of small diameter peripheral sensory nerve fibres, mediating in the desensitization of afferent nociceptors and causing reversible degeneration of peripheral sensory nerve endings, which consequently reduces the syndromic burning sensation [59]. Clonazepam, a benzodiazepine, is a GABAergic agonist that activates pain-inhibiting pathways in the spinal cord and peripheral nociceptors. When applied topically to the oral mucosa, clonazepam reduces the excitability of peripheral sensory nerve fibres, and when administered systemically, it has a sedative, anxiolytic and analgesic effect. Tan et al. confirmed that topical and systemic administration of clonazepam reduces the intensity of BMS [60].

From the clinical point of view, the efficacy of some antidepressants may be the best evidence pointing to a relationship with the dysregulation of certain neurotransmitters, including dopamine nervous systems, which are likely to affect complex neurological networks [61]. As reported by Cui et al., response to clonazepam in the study they conducted was more specific in women, while men required different categories of medications, such as tricyclic antidepressants, SSRIs, SNRIs and anticonvulsants [62]. Additionally, psychotherapy and behavioural feedback can also help in eliminating the symptoms of BMS. One of the elements of psychotherapy is cognitive behavioural therapy which is a targeted, structured, short-term psychological treatment aimed at correcting dysfunctional emotional responses, such as pain, fear, helplessness, sensitivity or exhaustion, by changing thoughts and behaviours [63]. Komiyama et al., showed that individual or small group cognitive behavioural therapy reduces the intensity of BMS in a significant number of patients, alone or with medication [64].

Oral candidiasis. This is one of the most common fungal infections in the oral cavity and affects the oral mucosa.
The main pathogen of this disease is the yeast Candida albicans, which is one of the components of the physiological microflora of the oral cavity, and about $30 \%-50 \%$ of the population are carriers of this organism, and this number increases with the age of the patient. Many other Candida species are present in the oral cavity besides the mentioned C. albicans, such as: C. glabrata, C. guillermondii, C. krusei, C. parapsilosis, C. pseudotropicalis, C. stellatoidea, C. tropicalis [65]. As reported by Wall et al., the main characteristic of C. albicans that affects its virulence is the ability to form biofilms on different surfaces, which is associated with most infections caused by this pathogen [66]. It should be noted that as a result of biofilm formation, the expression of Candida virulence factors increases, and the susceptibility to antimicrobial agents and phagocytosis decreases drastically [67].

A number of predisposing factors must be present for C. albicans to pass from a harmless commensal state to a pathogenic one. These factors can be divided into local and general. The first group includes qualitative and quantitative reduced salivation. Factors responsible for such state are, inter alia, age-related salivary gland hypofunction, weakened immune systems (e.g. HIV), and other iatrogenic therapies, such as chemotherapy and radiotherapy of the head and neck, causing deep injury to the salivary glands [68].

Another local factor is long-term wear and poor hygiene of dentures, as well as mucosal injuries. As a result of rupture of the epithelial layer of the cavity, an insertion site for Candida is formed. Another important element in the development of candidiasis associated with wearing prosthetic restoration is the favourable environment for the development of Candida underneath the denture. The microenvironment of the palate mucosa under the removable full denture is rich in saliva, poor in oxygen, has an acidic $\mathrm{pH}$, as well as being an ideal place for the xcessive development of yeast. Iinuma et al. found that at least $40 \%$ of elderly people wearing dentures did not disinfect or remove their dentures properly at night [69]. An important factor in favour of candidiasis in the presence of dentures in the oral cavity is also the material from which they were made, becausthist significantly affects the formation of biofilm. Acrylic dentures cause a five-fold higher risk of candidiasis compared to metal dentures [70]. Another local factor is the misuse of a steroid inhaler, which may induce candidiasis by inhibition of cellular immunity and phagocytosis, but local mucosal immunity returns to normal after discontinuation of inhaled steroids. Immuno-suppressive effects of this therapy lead to secondary candidiasis [71].

Smoking is also a local inducer of oral candidiasis. According to research by Mun et al., cigarette smokers have a significantly higher level of oral yeast carrier state, and are therefore at increased risk of developing the disease [72]. The mechanism by which conventional cigarette smoking induces oral candidiasis is not yet fully understood, but a plausible theory has emerged suggesting that smoking causes reduced saliva flow, and thus a decrease in oral $\mathrm{pH}$, which favours the colonization and growth of Candida. Manfredi et al. suggested that cigarette smoking may cause a decrease in immunoglobulin A (IgA) in saliva and inhibit neutrophil activity, promotthe oral colonization of Candida [73].

The most important of the general factors influencing the development of candidiasis is the age of the patient. As reported by Gasparo et al., elderly patients have a significantly lower level of protective activity of congenital salivary defence, 
and are therefore more likely to develop Candida fungi [74]. General factors also include the use of broad-spectrum antibiotics, which are responsible for the vast majority of acute cases of candidiasis. The use of these antibiotics leads to a change in the local flora of the oral cavity, creating a favourable environment for the multiplication of Candida. Also, any systemic disease, including HIV, which leads to systemic immuno-deficiency, regardless of its etiology, i.e. developmental, iatrogenic, immunological, autoimmune, endocrine or malignancy-related, can cause candidiasis [75].

Absorption disorders and states of eating disorders are also important in cases of the development of candidiasis; in particular, a diet rich in carbohydrates contributes to its development, and deficiencies of iron, zinc, magnesium, selenium, folic acid and vitamins (A, B6, B12 and C) induce the development of this disease [73].

It should be noted that several clinical forms can occur simultaneously in the oral cavity and in many places, and Candida species - other than albicans - can cause leukoplakia, the oral symptoms of which are always the same regardless of the causative species. There are several systems of classification of leukoplakia in relation to oral symptoms, which can be divided into three main broad categories, namely, 1) acute symptoms, 2) chronic symptoms and 3) syndromes of chronic mucocutaneous candidiasis.

Acute pseudomembranous candidiasis, ('[thrush'). Usually manifests itself as multi-focal, curly yellow-white plaque in the oral mucosa. Key feature of this type of candidiasis is that the plaques, which are made up of exfoliated epithelial cells and immune cells along with the yeasts and hyphae, can be removed by gentle scraping, leaving a red erosive base underneath [76].

Chronic atrophic erythematous candidiasis. Commonly seen as an extension of the acute form and is very common in people with HIV+. It is the most common as Candidaassociated stomatitis, manifested by erythema of the palate mucosa with the denture [77].

Chronic candidiasis of the skin and mucous membranes. Belongs to a group of rare heterogeneous immune disorders characterized by basic immuno-deficiencies. Patients with this disease suffer from chronic, in some cases lifelong or recurrent mucocutaneous candidiasis affecting the skin, nails and mucous membranes of the genital organs, and in more than $90 \%$ of patients occurred orally [78].

The basis of treatment of oral mycosis is a diet low in carbohydrates, highly processed products and products with a high glycaemic index. Enrichment of the diet is recommended with products containing live bacteria cultures, such as kefir, yogurt, sour milk, and consuming a significant amount of vegetables. An important role is also played by adequate hydration of the body (an intake of at least two liters of fluids per day), which acts prophylactically against an increase of the amount of toxins in the body. An important element of the diet used in the treatment of oral candidiasis are cold pressed vegetable oils that provide the body with omega- 3 acids. Adherence to the principles of healthy eating and the use of diet should be supplemented with equally important probiotic and prebiotic preparations [79].

Pharmacological antifungal treatment of oral candidiasis can be used topically or systemically. The former are applied only to the affected area and to treat limited infections, while systemic medicines are used in cases of more widespread infection, and when local treatment is insufficient. Antifungal preparations are sold as tablets, oral suspensions, gels, pastilles, mucoadhesive tablets, toothpastes, etc. [80]

Nystatin 100,000 IU / ml [5 ml four times per day] and amphotericin b 50mg [ $5 \mathrm{ml}$ three times per day] have been the primary choice for topical treatment for many years, whereas studies on 19 patients with pseudomembranous candidiasis have shown that in the case of administering fluconazole suspension in distilled water [ $2 \mathrm{mg} / \mathrm{ml}$ ], 95\% of patients recovered. Oral fluconazole (100-200 mg per day for seven to 14 days) is recommended for systemic treatment. It is also recommended for the treatment of moderate to severe oral candidiasis, while fluconazole at a dose of $100 \mathrm{mg}$ three times a week is recommended in patients with recurrent infections [81].

Leukoplakia. Pre-cancerous conditions are defined as 'morphologically altered tissue within which there is a higher probability of oral cancer than in unchanged tissue'. These include, inter alia, leukoplakia, erythroplakia, and changes associated with smokeless tobacco use, oral submucosal fibrosis, senile keratosis, lichen planus and discoid lupus erythematosus. These conditions can occur at any age, but most commonly affect the elderly above the age of 50, especially men [82].

Oral leukoplakia is defined as a white plaque in the lining of the oral mucosa and is one of the most common potentially malignant lesions in the mouth. In 2018, the World Health Organization (WHO) established the following definition of oral leukoplakia: 'white plaque of doubtful risk after exclusion of (other) known diseases or disorders that do not carry an increased risk of cancer' [83]. According to the literature, the rate of progression to invasive oral cancer is extremely variable and ranges from $0 \%-36 \%$ [84]. Anil et al. stated that oral leukoplakia is associated with a 40.8 -fold increased risk of oral cancer and a five-year absolute risk of 3.3\% (1 in 30 people with cancer progression over five years) [85].

The simplest division of leukoplakia includes two main clinical types: homogeneous and heterogeneous. An undoubted advantage of this division is the assumption that there is a correlation between the clinical type and the risk of malignant transformation. The heterogeneous type carries a higher risk of the above-mentioned transformation, and can be divided into different subtypes, such as speckled or erythematous (white and red lesions), also referred to as erythroleukoplakia, nodular and papillomatous. The homogenous type is characterized by a thin, flat and homogeneous whitish appearance [86].

Another division of leukoplakia distinguishes it into reactive or idiopathic. The first is associated with an external irritant, especially nicotine (more than $80 \%$ of cases). Another causal factor is alcohol, which alone does not cause leukoplakia, but acts synergistically with nicotinism [87]. The etiology of leukoplakia is also affected by HPV infection. De La Cour et al. in their studies found a cumulative incidence of HPV of $22.5 \%$ in a review of 52 studies with 2,677 cases of leukoplakia [88]. The elderly are much more likely to be affected by the transformation of this disease into cancer. Yanik et al. in their population study of the elderly in the USA found that people with oral leukoplakia had a significantly increased risk of developing cancer of the floor of the mouth [89]. The most 
common localization of leukoplakia is the mucous membrane of the cheeks in the corners of the mouth, palate, tongue, near the floor of the mouth. The disease is characterized by a chronic and slow course. The first symptoms are an uncharacteristic sensitivity during the consumption of spicy and sour foods, pain, burning, sometimes dryness and tingling. In the next stage of the disease, there appear different-sized, flat eruptions, slightly rising above the healthy mucosa. In the next stage of the disease, the lesions take on a patchy appearance, are thickened and diffused, an inflammatory edge (Schwimmer's edge) appears, as well as papillary growths, cracks, infiltrations and hardening of the substrate being present [90]. White spots with signs of pronounced cornification on the mucous membrane of the cheeks, tongue or floor of the mouth, should be of concern to the doctor examining the oral cavity and the patient should be referred for further diagnosis by a dentist.

In the context of treatment of leukoplakia, a period of four to eight weeks after removal of the possible cause should be considered, which is a practical and safe waiting period for such a change to resolve spontaneously. The current standard of treatment for oral leukoplakia is biopsy for histopathological evaluation and exclusion of other mucosal disorders [91]. The main goal of treatment of leukoplakia of the oral cavity is early diagnosis and prevention of malignant transformation. Firstly, the patient should be motivated to abstain from risky activities, such as smoking. The further treatment plan will depend on the degree of dysplasia assessed in histopathological examination. Oral leukoplakia without the features of dysplasia, which has a low risk of malignancy, can be removed completely or incompletely, and the doctor making the decision should take into account other factors, such as the location of the lesion, its size, and, in the case of smokers, the patient's involvement in the fight against addiction. If moderate to severe epithelial dysplasia is diagnosed, surgical treatment is recommended, which may include conventional surgery or laser ablation, electrocautery or cryosurgery [92].

\section{CONCLUSIONS}

All the oral cavity health conditions mentioned in the study affect the well-being, i.e. physical and mental health of a patient. Local pathological states, such as prosthetic stomatopathies, are resolved mainly by eliminating the cause of contact inflammation. Other ailments, periodontitis, BMS, leukoplakia, oral candidiasis or xerostomia, are closely related to the general condition of the patient. Changes in oral cavity depend on the intensity and stabilization of the general disease, which is why attending physicians, general practitioners, diabetologists, neurologists or psychiatrists play a very important role. The cooperation of a dentist with a general practitioner can significantly improve the health of geriatric patients.

\section{REFERENCES}

1. Koczorowski R. Prosthodontics for the geriatric patient. Conventional and implant prosthetic restorative methods. Poznań: Wydawnictwo Naukowe Uniwersytetu Medycznego; 2011.

2.Kulik TB, Janiszewska M, Piróg E, et al. Sytuacja zdrowotna osób starszych w Polsce i w innych krajach europejskich. Med Og Nauk Zdr. 2018; 17(2): 90-95.
3. Gauch, LMR, Silveira-Gomes F, Pedrosa SS, et al. Relationship among local and functional factors in the development of denture stomatitis in denture wearers in northern Brazil. Rev odontol UNESP. 2014; 43(5): 314-8. https://dx.doi.org/10.1590/rou.2014.050

4. Arnaud RR, Soares MSM, Santos MGC, et al. Denture stomatitis: prevalence and correlation with age and gender. R Bras Ci Saúde. 2012; 16(1): 59-62.

5. Gendreau L, Loewy ZG. Epidemiology and etiology of denture stomatitis. J Prosthodont. 2011;20(4): 251-260. https://doi.org/10.1111/ j.1532-849X.2011.00698.x

6. Spiechowicz E. Protetyka stomatologiczna. Warszawa: PZWL; 2016.

7.Smolana A, Szypowska A, Wieczorek A, et al. Analiza nawyków higienicznych oraz stanu błony śluzowej jamy ustnej u pacjentów użytkujących akrylowe protezy ruchome. J Stoma. 2017; 70(3): 250-260. https://doi10.5604/01.3001.0010.5018

8. Kubicka K, Godlewski T. Interdyscyplinarne leczenie pacjenta z ziarninującym stanem zapalnym błony śluzowej jamy ustnej opis przypadku. Protet Stomatol. 2018; 68(3): 319-326. https://doi. org/10.5604/01.3001.0012.2562

9. Cierech M, Szczypińska A, Wróbel K, et al. Analiza porównawcza chropowatości tworzyw akrylowych stosowanych w wykonawstwie protez płytowych oraz przylegania do nich grzybów Candida albicans - badania in vitro. Dental and Medical Problems. 2013; 50(3): 341-347.

10. Gauch, LMR, Pedrosa SS, Silveira-Gomes F, et al. Isolation of Candida spp. from denture-related stomatitis in Pará. Braz J Microbiol. 2018; 49(1): 148-151. https://doi.org/10.1016/j.bjm.2017.07.001

11. Cierech M, Kolenda A, Osica I, et al. Wpływ fotopolimeryzującej żywicy łączącej na wybrane właściwości fizykochemiczne powierzchni tworzywa akrylowego. Dent Med Probl. 2015; 52(3): 298-303.

12. Prabowo DMS, Widodo HB. Nicotine stomatitis in smokers: a case report. J Dentomaxillofac Sci. 2018; 3(1): 58-60. https://doi.org/10.15562/ jdmfs.v3i1.708

13. Jones KB, Jordan R. White lesions in the oral cavity:clinical presentation, diagnosis and treatment. Semin Cutan Med Surg. 2015; 34: 161-170. https://doi.org/10.12788/j.sder.2015.0180

14. Aoun G, Cassia A. Evaluation of denture-related factors predisposing to denture stomatitis in a Lebanese population. Mater Sociomed. 2016; 28(5): 392-6. https://doi.org/10.5455/msm.2016.28.392-396

15. de Arruda CNF, Salles MM, Badaro MM, et al. Effect of sodium hypochlorite and Ricinus communis solutions on control of denture biofilm: A randomized crossover clinical trial. Journal of Prosthetic Dentistry. 2017; 117(6): 729-34. https://doi.org/10.1016/j. prosdent.2016.08.035

16. Leite DP, Piva MR, Martins-Filho PRS. Identification of Candida species in patients with denture stomatitis and evaluation of susceptibility to miconazole and photodynamic therapy. Rev Odontol UNESP. 2015; 44(1): 12-7. https://doi.org/10.1590/1807-2577.1027

17. Czerninski R, Pikovsky A, Gati I, et al. Comparison of the efficacy of a novel sustained release clotrimazole varnish and clotrimazole troches for the treatment of oral candidiasis. Clinical Oral Investigations. 2015; 19(2): 467-73. doi: 10.1007/s00784-014-1259-5

18. Acosta-Torres LS, Mendieta I, Nuñez-Anita RE, et al. Cytocompatible antifungal acrylic resin containing silver nanoparticles for dentures. Int J Nanomedicine. 2012; 7: 4777-86. https://doi.org/10.2147/IJN.S32391

19. Mauri-Obradors E, Jané-Salas E, Sabater-Recolons MDM, et al. Effect of nonsurgical periodontal treatment on glycosylated hemoglobin in diabetic patients: a systematic review. Odontology. 2014; 103: 301-13. https://doi.org/10.1007/s10266-014-0165-2

20.Zalewska A, Knaś M, Maciejczyk M, et al. Antioxidant profile, carbonyl and lipid oxidation markers in the parotid and submandibular glands of rats in different periods of streptozotocin induced diabetes. Archives of Oral Biology. 2015; 60(9): 1375-1386. https://doi.org/10.1016/j. archoralbio.2015.06.012.

21. Bajaj S, Prasad S, Gupta A, et al. Oral manifestations in type-2 diabetes and related complications. Indian J Endocr Methab. 2012; 16: 777-779. https://doi.org/10.4103/2230-8210.100673

22. Lim SG, Han K, Kim HA, et al. Association between insulin resistance and periodontitis in Korean adults. J Clin Periodontol. 2013; 41(2): 121-30. https://doi.org/10.1111/jcpe.12196

23. Wyszyńska M, Naporal M, Grabowska E, et al. Stan przyzębia u pacjentów ze świeżo rozpoznaną i leczoną cukrzycą typu II - analiza porównawcza. Dent. Med. Probl. 2016; 53(4): 459-467.

24. Grover HS, Luthra S. Molecular mechanisms involved in the bidirectional relationship between diabetes mellitus and periodontal disease. J Indian Soc Periodontol. 2013; 17: 292-301. https://doi. org/10.4103/0972-124X.115642 
25. Wilczyńska-Borawska M, Zbroch E, Małyszko J, et al. Stan uzębienia i przyzębia chorych na cukrzycę pacjentów hemodializowanych z terenu północno-wschodniej Polski. Postępy Nauk Medycznych. 2013; 26(3): 195-200.

26. Mauri-Obradors E, Estrugo-Devesa A, Jané-Salas E, Viñas, et al. Oral manifestations of Diabetes Mellitus. A systematic review. Med Oral Patol Oral Cir Bucal. 2017; 22(5): e586-e594. https://doi.org/10.4317/ medoral.21655

27. Simpson TC, Weldon JC, Worthington HV, et al. Treatment of periodontal disease for glycaemic control in people with diabetes mellitus. Cochrane Database Syst Rev. 2015; 11: CD004714. https:// doi.org/10.1002/14651858.CD004714.pub3

28. Lewusz K, Perz A, Godzieba A, et al. Pacjent z cukrzycą w gabinecie stomatologicznym. Magazyn Stomatologiczny. 2016; 3: 74-78.

29. Obradović RR, Kesić LG, Pejčić AN, et al. Diabetes mellitus and oral candidiasis. Acta Stomatologica Naissi. 2011;27(63): 1025-1034. https:// doi.org/10.5937/asn1163025O

30. Premkumar J, Ramani P, Chandrasekar T, et al. Detection of species diversity in oral Candida colonization and anti-fungal susceptibility among non-oral habit adult diabetic patients. J Nat Sci Biol Med. 2014; 5(1): 148-54. https://doi.org/10.4103/0976-9668.127315

31. Gomes CC, Guimaraes LS, Pinto LCC, et al. Investigations of the prevalence and virulence of Candida albicans in periodontal and endodontic lesions in diabetic and normoglycemic patients. J Appl Oral Sci. 2017; 25(3): 274-281. https://doi.org/10.1590/1678-7757-2016-0432

32. National institute of Diabetes and Digestive and Kidney Diseases. Diabetes, Gum Disease, \& Other Dental Problems. 2017. https://www. niddk.nih.gov/health-information/diabetes/overview/preventingproblems/gum-disease-dental-problems. (access: 2020.08.25).

33. Cohen B, Thomson H. Dental Care for the Elderly. Chicago: Boca Raton, 2016.

34. Yap T, McCullough M. Choroby jamy ustnej, a starzejące się społeczeństwo. Med Prakt Stomatol. 2015; 3: 15-26.

35. Johansson AK, Johansson A, Unell L, et al. Self reported dry mouth in Swedish population samples aged 50,65 and 75 years. Gerodontology. 2012; 29(2): 107-110. https://doi.org/10.1111/j.1741-2358.2010.00420.x

36. Minicucci EM, Pires RBC, Vieira RA, et al. Assessing the impact of menopause on salivary flow and xerostomia. Aust Dent J. 2013; 58(2): 230-234. https://doi.org/10.1111/adj.12057

37. Maciejczyk M, Dąbrowska BM, Sawczuk B, et al. Polekowe zaburzenia wydzielania śliny: Znaczenie kliniczne. Magazyn Stomatologiczny. 2015; 5: 123-126.

38. Dutkowska A, Brukwicka I, Kopański Z, et al. Kserostomia u ludzi w podeszłym wieku. Journal of Clinical Healthcare. 2017; 2: 20-23.

39. Walis M, Szymczak-Paluch M, Kłosek S. Profilaktyka i leczenie zmian w jamie ustnej u pacjentów onkologicznych. Onkol Dypl. 2016; 13(2): 22-30.

40. Walis M, Kłosek S. Częstość występowania suchości w jamie ustnej u pacjentów po 65. roku życia. Gerontologia Polska. 2018; 26: 190-195.

41. Spagnoli A, Ostino G, Borga AD, et al. Drug Compliance and Unreported Drugs in the Elderly. J Am Geriatr Soc. 2015; 37(7): 619-624. https:// doi.org/10.1111/j.1532-5415.1989.tb01252.x

42. Węgrzyn M, Wróbel A, Roemer-Ślimak R, et al. Kserostomia u pacjentów geriatrycznych. Problemy i możliwości terapeutyczne - przegląd literatury. Forum Medycyny Rodzinnej. 2018; 2(5): 197-203.

43. Rehan F, Khan BR, Memon MS, et al. Analysis of resting mouth salivary flow rate and salivary $\mathrm{pH}$ of tobacco chewers and smokers. J Pak Dent Assoc. 2016; 4: 159-63.

44. Shubha G, Fasalkar SS, Praveen BN, et al. Assessment of salivary flow rate and salivary $\mathrm{pH}$ in subjects with smoking and smokeless form of tobacco habits. Journal of Medicine, Radiology, Pathology \& Surgery. 2018; 5: 11-15. https://doi.org/10.15713/ins.jmrps.142

45. Mystkowska J, Car H, Dąbrowski JR, et al. Artificial Mucin-based Saliva Preparations - Physicochemical and Tribological Properties. Oral Health \& Preventive Dentistry. 2018; 16(2): 183-193. https://doi. org/10.3290/j.ohpd.a40304

46. Villa A, Connell CL, Abati S. Diagnosis and management of xerostomia and hyposalivation. Ther Clin Risk Manag. 2015; 11: 45-51. https://doi. org/10.2147/TCRM.S76282

47. Netto FO, Diniz IM, Grossmann SM, et al. Risk factors in burning mouth syndrome: a case-control study based on patient records. Clin Oral Investig. 2011; 15: 571-575. https://doi.org/10.1007/s00784-010-0419-5

48. Sardella A, Lodi G. Acupuncture and burning mouth syndrome: a pilot study. Pain Pract. 2013; 13: 627-632. https://doi.org/10.1111/papr.12031

49. Kohorst JJ, Bruce AJ, Torgerson RR, et al. The Prevalence of Burning Mouth Syndrome: A Population-Based Study. Br J Dermatol. 2015; 172(6): 1654-1656. https://doi.org/10.1111/bjd.13613
50. Schiavone V, Adamo D, Ventrella G, et al. Anxiety, depression, and pain in burning mouth syndrome: first chicken or egg? Headache. 2012; 52: 1019-1025. https://doi.org/10.1111/j.1526-4610.2012.02171.x

51. Souza FTA, Santos TPM, Bernardes VF, et al. The impact of burning mouth syndrome on health-related quality of life. Health and Quality of Life Outcomes. 2011; 9(57). https://doi.org/10.1186/1477-7525-9-57

52. Sun A, Lin HP, Wang YP, et al. Significant reduction of serum homocysteine level and oral symptoms after different vitaminsupplement treatments in patients with burning mouth syndrome. J Oral Pathol Med. 2013; 42(6): 474-479. https://doi.org/10.1111/jop.12043

53. López-Jornet P, Camacho-Alonso F, Molino-Pagan D. Prospective, randomized, double-blind, clinical evaluation of Aloe vera Barbadensis, applied in combination with a tongue protector to treat burning mouth syndrome. J Oral Pathol Med. 2013; 42: 295-301. https://doi.org/10.1111/ jop. 12002

54. de Moraes M, do Amaral Bezerra BA, da Rocha Neto PC, et al. Randomized trials for the treatment of burning mouth syndrome: an evidence-based review of the literature. J Oral Pathol Med. 2012; 41: 281-287. https://doi.org/10.1111/j.1600-0714.2011.01100.x

55. Corsalini M, di Venere D, Pettini F, et al. Temporomandibular disorders in burning mouth syndrome patients: an observational study. Int J Med Sci. 2013; 10(12): 1784-1789. https://doi.org/10.7150/ijms.6327

56. Morr Verenzuela CS, Davis MDP, Bruce AJ, et al. Burning mouth syndrome: results of screening tests for vitamin and mineral deficiencies, thyroid hormone, and glucose levels-experience at Mayo Clinic over a decade. Int J Dermatol. 2017; 56(9): 952-956. https://doi.org/10.1111/ijd.13634

57. Watanabe M, Nakatani E, Yoshikawa H, et al. Oral soft tissue disorders are associated with gastroesophageal reflux disease: retrospective study. BMC Gastroenterol. 2017; 17(1): 92. https://doi.org/10.1186/s12876017-0650-5

58. Tu TTH, Takenoshita M, Matsuoka H, et al. Current management strategies for the pain of elderly patients with burning mouth syndrome: a critical review.Biopsychosoc Med. 2019; 13: 1. https://doi.org/10.1186/ s13030-019-0142-7

59. Laklouk M, Baranidharan G. Profile of the capsaicin $8 \%$ patch for the management of neurolppathic pain associated with postherpetic neuralgia: Safety, efficacy, and patient acceptability. Patient Preference and Adherence. 2016; 10: 1913-1918. https://doi.org/10.2147/PPA.S76506

60. Tan SN, Song E, Dong XD, et al. Peripheral GABAA receptor activation modulates rat tongue afferent mechanical sensitivity. Archives of Oral Biolog. 2013; 59(3): 251-257.

61. Jääskeläinen SK, Woda A. Burning mouth syndrome. Cephalalgia. 2017; 37(7): 627-647. https://doi.org/10.1177/0333102417694883

62. Cui Y, Xu H, Chen FM. Efficacy evaluation of clonazepam for symptom remission in burning mouth syndrome: a meta-analysis. Oral Dis. 2016; 22: 503-511. https://doi.org/10.1111/odi.12422

63. Kaczkurkin AN, Foa EB. Cognitive-behavioral therapy for anxiety disorders: An update on the empirical evidence. Dialogues in Clinical Neuroscience. 2015; 17(3): 337-346.

64. Komiyama O, Nishimura H, Makiyama Y, et al. Group cognitivebehavioral intervention for patients with burning mouth syndrome. Journal of oral science. 2013; 55(1): 17-22. https://doi.org/10.2334/ josnusd.55.17.

65. Terezhalmy GT, Huber MA. Oropharyngeal candidiasis: Etiology, epidemiology, clinical manifestations, diagnosis, and treatment. Crest Oral-B at dentalcare.com Contin Educ Course. 2011; 1-16.

66. Wall G, Montelongo-Jauregui D, Vidal Bonifacio B, et al. Candida albicans biofilm growth and dispersal: Contributions to pathogenesis. Curr. Opin. Microbiol. 2019; 11: 1-6. https://doi:10.1016/j.mib.2019.04.001

67. Jabra-Rizk MA, Kong E, Tsui C, et al. Candida albicans pathogenesis: Fitting within the host-microbe damage response framework. Infect. Immun. 2016; 84: 2724-2739. https://doi: 10.1128/IAI.00469-16

68. Sroussi HY, Epstein JB, Bensadoun RJ, et al. Common oral complications of head and neck cancer radiation therapy: Mucositis, infections, saliva change, fibrosis, sensory dysfunctions, dental caries, periodontal disease, and osteoradionecrosis. Cancer Med. 2017; 6: 2918-2931. https:// doi: $10.1002 / \mathrm{cam} 4.1221$

69. Iinuma T, Arai Y, Abe Y, et al. Denture wearing during sleep doubles the risk of pneumonia in the very elderly. J. Dent. Res. 2015; 94: 28S-36S. https://doi: 10.1177/0022034514552493

70. Scully C, Giovanni L. Denture Related Stomatitis. European Association of Oral Medicine. http://www.eaom.eu/pdf/content/denture_related_ stomatitis.pdf. (dostęp: 2020.12.24)

71. Tejani S, Sultan A, Stojanov I, et al. Candidal carriage predicts candidiasis during topical immunosuppressive therapy: A preliminary retrospective cohort study. Oral Surg. Oral Med. Oral Pathol. Oral Radiol. 2016; 122: 448-454. https://doi:10.1016/j.oooo.2016.06.012. 
72. Mun M, Yap T, Alnuaimi AD, et al. Oral candidal carriage in asymptomatic patients. Aust. Dent. J. 2016; 61: 190-195. https:// doi:10.1111/adj.12335

73. Manfredi MPL, Giovati L, Alnuaimi A, et al. Oral and Maxillofacial Fungal Infections. In: Farah C, Balasubramaniam R, McCullough M, editors. Contemporary Oral Medicine. Berlin/Heidelberg, Germany: Springer; 2018

74. Gasparoto TH, de Oliveira CE, Vieira NA, et al. The pattern recognition receptors expressed on neutrophils and the associated cytokine profile from different aged patients with Candida-related denture stomatitis. Exp Gerontol. 2012; 47: 741-748. https://doi: 10.1016/j.exger.2012.07.003

75. Vila T, Sultan AS, Montelongo-Jauregui D, et al. Oral Candidiasis: A Disease of Opportunity. J Fungi (Basel). 2020; 6(1): 15. https://doi: 10.3390/jof6010015

76. Hellstein JW, Marek CL. Candidiasis: Red and white manifestations in the oral cavity. Head Neck Pathol. 2019; 13: 25-32. https://doi:10.1007/ s12105-019-01004-6

77. Sultan AS, Rizk AM, Vila T, et al. Digital design of a universal rat intraoral device for therapeutic evaluation of topical formulation against Candida-associated denture stomatitis. Infect Immun. 2019; 87(12): e00617-19. https://doi:10.1128/IAI.00617-19

78. Humbert L, Cornu M, Proust-Lemoine E, et al. Chronic mucocutaneous candidiasis in autoimmune polyendocrine syndrome Type 1. Front. Immunol. 2018; 9: 2570. https://doi: 10.3389/fimmu.2018.02570

79. Jopek-Sady A. Grzybica jamy ustnej. Praca specjalizacyjna z zakresu farmacji aptecznej, Kołobrzeg, https://docplayer.pl/2059475-Grzybicajamy-ustnej.html (access: 2020.12.26).

80. Scheibler E, Garcia MCR, Medina da Silva R, et al. Use of nystatin and chlorhexidine in oral medicine: Properties, indications and pitfalls with focus on geriatric patients. Gerodontology. 2017; 34: 291-8.

81. Garcia-Cuesta C, Sarrion-Pérez MG, Bagán JV. Current treatment of oral candidiasis: A literature review. J Clin Exp Dent. 2014; 6(5): e576-e582. https://doi:10.4317/jced.51798

82. Kamiński T, Szerszeń M, Wiśniewska J, et al. Wczesna diagnostyka wizualizacyjna $\mathrm{w}$ raku płaskonabłonkowym błony śluzowej jamy ustnej: opis przypadku. Protet Stomatol, 2017; 67(4): 374-380. https:// doi:10.5604/01.3001.0010.6864

83. Reibel J, Gale N, Hille J, et al. Tumours of the oral cavity and mobile tongue. In: El-Naggar AK, Chan JKC, Grandis JR, et al. eds. WHO classification of head and neck tumours, 4th ed. Lyon: IARC press; 2017. p. 112-4

84. Warnakulasuriya S, Ariyawardana A. Malignant transformation of oral leukoplakia: a systematic review of observational studies. J Oral Pathol Med. 2016; 45(3): 155-166.

85. Chaturvedi AK, Udaltsova N, Engels EA, et al. Oral Leukoplakia and Risk of Progression to Oral Cancer: A Population-Based Cohort Study. J Natl Cancer Inst. 2020; 112(10): 1047-1054. https://doi:10.1093/jnci/ djz238

86. van der Waal I. Oral leukoplakia, the ongoing discussion on definition and terminology. Med Oral Patol Oral Cir Bucal. 2015; 20(6): e685-e692. https://doi: 10.4317/medoral.21007

87. Górska R, Nowak M. Selected issues about diagnosis and treatment of the oral mucose membrane; Pol Otorhino Rev. 2017; 6(2): 14-22. https:// doi: 10.5604/01.3001.0010.1026

88. De la Cour CD, Sperling CD, Belmonte F, et al. Human papillomavirus prevalence in oral potentially malignant disorders: Systematic review and meta-analysis. Oral Dis. 2020. https://doi: 10.1111/odi.13322

89. Yanik EL, Katki HA, Silverberg MJ, et al. Leukoplakia, oral cavity cancer risk, and cancer survival in the US elderly. Cancer Prev Res (Phila). 2015; 8(9): 857-863. https://doi: 10.1158/1940-6207.CAPR-15-0091

90. Dutkowska A, Brukwicka I, Kopański Z, et al. Zmiany w błonie śluzowej jamy ustnej i języka u ludzi w starszym wieku. Journal of Clinical Healthcare. 2017; 2: 16-19.

91. Lodi G, Franchini R, Warnakulasuriya S, et al. Interventions for treating oral leukoplakia to prevent oral cancer. Cochrane Database Syst Rev. 2016; 7: CD001829.

92. Brouns E, Baart JA, Bloemena E, et al. The relevance of uniform reporting in oral leukoplakia: Definition, certainty factor and staging based on experience with 275 patients. Med Oral Patol Oral Cir Bucal. 2012: 18756-18756. 